\title{
КРИМННАЛЬНО-ПРАВОВА ХАРАКТЕРИСТИКА КРИМІНАЛЬНИХ ПРАВОПОРУШЕНЬ У СФЕРІ БЕЗПЕКИ ДОРОЖНЬОГО РУХУ
}

\author{
ЖУЧЕНКО Свгеній Юрійович \\ університету внутрішніх справ \\ - аспірант Донецького державного \\ УДК 342.9:343.346.2(075.8) \\ DOI 10.32782/NP.2021.3.13
}

\begin{abstract}
У статті автор надає кримінально-правову характеристику кримінальних правопорушень у сбері безпеки дорожнъого руху. Вказується на відсутність вичерпної наукової оцінки беномену об’єкта кримінального правопорушення. Наразі наявна низка наукових досліджень у иій изарині, оскільки саме об'єкт відіграє провідну роль у формуванні розділів кримінального законодавства, оскільки він дозволяе створити певну сукупність протиправних діянь за однотипним мотивом та метою, при изьому більшість питань залишаються невирішеними. Автор вказує на віддання переваги стандартному підходу прихильників вітчизняного кримінального права, відповідно до якого, об'єкт кримінального правопорушення - це, у першу чергу, суспільні відносини у тій чи іншій галузі. Вказується, що в контексті статті, здебільшого, безпосереднім об'єктом є безпека руху й експлуатациі автомобільного та деяких інших видів транспорту, а його додатковим обов'язковим об'єктом - життя $i$ здоров'я особи, а також власність. Зазначається, що передбачені у кримінальному законодавстві иінності вказують на підвищену суспільну небезпечність кримінальних правопорушень у сбері безпеки дорожнъого руху, котрі мають складну та розгалужену систему суспільно небезпечних наслідків. Саме у зв'язку із иим у 2021 році законодавцем було значно посилено кримінальну відповідальність за иі кримінальні правопорушення (особливо, ие стосується Загальної частини
\end{abstract}

КК України в частині особливостей звільнення від кримінальноӥ відповідальності та покарання), а також доповнено Кримінальний кодекс 2001 року нормою під номером 286-1, яка передбачає відповідальність за порушення правил безпеки дорожнього руху або експлуатаиї транспорту особами, які керують транспортними засобами в стані сп'яніння. Підсумовується, шо такий підхід є изілком зрозумілим, оскільки відповідно до статистичних даних, саме керування транспортним засобом у стані сп'яніння стає причиною більшості дорожнъо-транспортних пригод.

Ключові слова: кримінальне правопорушення, кримінально-правова характеристика, безпека, дорожній рух, транспорт, водій, транспорті засоби, стан сп'яніння.

\section{Постановка проблеми}

Юридична галузь наукових знань - одна 3 пріоритетних, що можна пояснити орієнтованістю на захист прав та свобод людини та громадянина. Особливого значення в цьому контексті набуває кримінальне законодавство, котре захищає найважливіші цінності, однією з яких є життя та здоров'я. Варто відмітити, що останні часто є предметом низки суспільно небезпечних діянь, одними з яких 6 кримінальні правопорушення у сфері безпеки дорожнього руху. На сьогодні останні не можна назвати такими, що мають незначний кримінологічний індекс, що пояснюється низкою чинників, серед яких основним, як здається, є відсутність 


\section{Кримінальне право, кримінальний процес та криміналістика}

ефективних кримінально-правових засобів та заходів протидії. Останнє можна пояснити недостатньою науковою розробленістю, а також прогалинами у кримінально-правовій характеристиці цього блоку протиправних діянь. Отже, враховуючи вказане, вважаємо за доцільне зупинитись на цій проблемі більш детально.

\section{Аналіз останніх досліджень та публікацій}

На сьогодні кримінальні правопорушення у сфері дорожнього руху залишаються не в повній мірі дослідженими. Окремі аспекти зустрічаються в працях таких учених, як Б.Ю. Бурбело, В.Г. Ковальов,B.А. Мисливий, В.І. Осадий,А.І. Перепелиця, С.I. Саєнко, А.О. Сабакарь, В.П. Тихий, М.ภ. Шелухін та ін.

Метою статті $\epsilon$ надання кримінальноправової характеристики кримінальних правопорушень у сфері безпеки дорожнього руху.

\section{Виклад основного матеріалу}

Відтак, як правильно відзначають учені, юридична традиція зумовлює необхідність проводити кримінально-правову характеристику злочинів за такою схемою: об'єкт, об'єктивна сторона, суб'єкт, суб'єктивна сторона злочину. Проблема об'єкта злочину хоча й не нова, але одна 3 найважливіших у науці кримінального права. Будь-яке кримінально-правове дослідження проблеми відповідальності за конкретний злочин або групу однорідних злочинів, насамперед, як вихідну позицію, передбачає аналіз об'єкта злочину. У свою чергу, виокремлення та групування злочинів за узагальнюючим їх об'єктом створює сприятливі умови для детального та багатостороннього аналізу певної групи суспільних відносин у конкретній сфері людської діяльності. Однією з таких сфер є безпека руху та експлуатації транспорту, кримінально-правовій охороні якої присвячений розділ XI Особливої частини Кримінального Кодексу України. За об'єктом злочину приховується, перш за все, природа тієї чи іншої категорії злочинів, того чи іншого конкретного складу. Об’єкт злочину визна- чає механізм самого впливу на нього, а отже, визначає специфіку ознак об'єктивної сторони злочину, характеризуючи діяння, спосіб його здійснення, характер шкоди тощо [1, с. 47].У цьому контексті мова йде про відсутність вичерпної наукової оцінки феномену об'єкта кримінального правопорушення. Звичайно, наразі ми маємо низку наукових досліджень у цій царині, оскільки саме об'єкт відіграє провідну роль у формуванні розділів кримінального законодавства, оскільки він дозволяє створити певну сукупність протиправних діянь за однотипним мотивом та метою, при цьому більшість питань залишаються невирішеними.

у межах останньої тези очевидним $є$ i той факт, що не менш важливим є значення об'єкта для встановлення суб'єктивної сторони; форми і виду вини, мотивів і мети скоєння злочину. Протягом багатьох років у науці радянського кримінального права було загальновизнаним, що об'єкт злочину - це суспільні відносини, на які посягає злочин, завдаючи їм певної шкоди і які знаходяться під охороною закону про кримінальну відповідальність. Прихильниками такої концепції залишається більшість сучасних українських вчених та науковців країн - наступниць республік колишнього СРСР. Однак останніми роками ця позиція піддається критиці. 3'явилася думка, що таке розуміння об'єкта є застарілим, загальним і розпливчастим, грунтується на перебільшенні значення категорії «публічного» до категорії «приватного» у сфері соціального життя i відсуненні людини $з$ іï потребами та інтересами на другий план; не дозволяє правильно визначати об'єкт злочинного посягання більшості злочинів; є неспроможним у вирішенні практичних питань кваліфікації злочинів тощо. Так, російський вченийА.В. Наумов, не заперечуючи, що в багатьох злочинах суспільні відносини - це об'єкт, водночас стверджує, що на деякі злочини таке розуміння об'єкта не поширюється і тому, на його думку, для встановлення об'єктів цілої низки злочинів необхідне повернення до теорії об'єкта як правового блага, створеної ще наприкінці минулого століття в межах класичної та соціологічної шкіл кримінального права. 
Кримінальними правопорушеннями проти безпеки руху та експлуатації транспорту є сукупність кримінальних правопорушень, якими була заподіяна або була створена небезпека заподіяння шкоди життю і здоров'ю людей, власності, іншим соціальним цінностям внаслідок руху або експлуатації різних видів транспортних засобів, а також функціонування матеріальної інфраструктури об'єктів транспорту [1, с. 47-48]. Ми віддаємо перевагу стандартному підходу прихильників вітчизняного кримінального права, відповідно до якого, об’єкт кримінального правопорушення - це, у першу чергу, суспільні відносини у тій, чи іншій галузі.У контексті нашого дослідження безпосереднім об'єктом є безпека руху й експлуатації автомобільного та деяких інших видів транспорту, а його додатковим обов' язковим об’єктом - життя і здоров'я особи, а також власність

У розділі ХІ Особливої частини КК України ці кримінальні правопорушення розташовано в певній послідовності. При цьому враховується тяжкість кримінального правопорушення, а також вид транспорту, яким воно вчиняється. Першими розташовано кримінальні правопорушення, які вчиняються на залізничному, водному чи повітряному транспорті (статті 276 -285 КК), наступні - на автомобільному i міському електротранспорті (статті 286 - 290 КК). Завершують главу злочини, що виражаються в порушенні чинних на транспорті правил та в пошкодженні магістральних трубопроводів (статті 291 і 292 КК) [2, с. 7]. На наш погляд, таке розташування діянь 6 достатньо логічним, оскільки максимально суспільно небезпечним необхідно вважати саме автомобільний та міський електротранспорт, що можна пояснити певною складністю керування та особливостями гальмівної системи.

Аксіологічне дослідження права має важливе наукове, практичне та моральне значення, оскільки дозволяє звернути увагу не тільки на соціокультурні засади та детермінанти права, зв'язок з державою, але й на його духовні аспекти, ідеали, рівень свідомості суспільства. Без ціннісного підходу до права неможливо виявити його призначення в загальнолюдському, соціальному та культурному розвитку, зрозуміти його специфічну природу. До того ж, аксіологічне дослідження правової реальності, права в цілому або окремої його галузі надає можливість говорити про дотримання або недотримання загальновизнаних людських цінностей, ідеалів та стандартів у тій або іншій державі. Це, перш за все, стосується аксіологічного дослідження кримінального права, норми якого мають застосовуватися як крайній, останній засіб, коли засоби регулювання суспільних відносин інших галузей права залишаються безсилими та недієвими [1, с. 49]. Прийнято вважати, що використання поняття «цінність» пов'язується з ім'ям I. Канта. Цінність у його трактовці - це те, що має значення повинності та свободи. Апріорний світ повинності конструюється I. Кантом у відриві та протиставленні до світу сущого, де панують причинно-наслідкові зв'язки та необхідність. Мова, таким чином, йде про нормативне та регулятивне значення цінностей, які становлять, за I. Кантом, апріорні нормативи розуму - цілі, вимоги, формули та максими повинності.3 цією моральною повинністю пов'язані й ті категоричні імперативи, що формулюються I. Кантом відносно моралі та права [3]. Виходячи з філософського розуміння суспільно небезпечних діянь взагалі та кримінальних правопорушень у сфері дорожнього руху зокрема, можна сказати, що формули та максими повинності у цьому випадку замінюються реаліями у вигляді ставлення водія та пішоходів до своїх прав та обов'язків, а також об'єктивними умовами дорожнього руху, котрі обумовлюють порушення його правил.

Кримінальне право, як галузь права України, має певні особливості. Ці особливості полягають у тому, що воно: 1) є галуззю публічного права; 2) охороняє найбільш значущі цінності суспільного буття; 3) охороняє зазначені цінності від суспільно небезпечних діянь, які визнаються злочинами; 4) спосіб охорони - застосування кримінальної відповідальності, головною формою якої є покарання осіб, які вчинили злочин. Підсумком аксіологічного пізнання права, як, власне, і всього соціального світу, є праксеологічно-світоглядна істина, вихід- 


\section{Кримінальне право, кримінальний процес та криміналістика}

на до мети (цілей) розвитку соціуму. I якщо такою метою стають права людини не лише як Homo juridicus, aле і як етичної моральної істоти, а також правові засоби їх захисту, то така концепція праворозуміння має всі шанси затвердитись як умова, що визначає домінуючий у суспільстві тип правосвідомості й правового світогляду. У теорії кримінального права прийнято вважати, що міра покарання (його вид і розмір), встановлена в кримінально-правовій санкції, обирається законодавцем, виходячи з суспільної небезпечності злочину (його тяжкості). Санкція кримінально-правової норми виконує свою службову роль тільки в тому разі, якщо іï мінімальна і максимальна межі відповідають суспільній небезпечності злочину. Однак суспільна небезпечність злочину (його тяжкість), відповідно до положень ст. 12 КК України, залежить від міри покарання, передбаченої в санкції статті (частини) за конкретний злочин. Як бачимо: законодавчо встановлена міра покарання визначається суспільною небезпечністю злочину, а суспільна небезпечність злочину - законодавчо встановленою мірою покарання. 3 позиції формальної логіки подібний стан речей називають «замкненим колом», О. Аитвак взагалі називає це коло «порочним». Як справедливо зазначає М. Хавронюк, вказівка на суспільну небезпечність діяння існує нібито для виду, як декларація про наміри [1, с. 49]. У кримінально-правовому розумінні цінність та мораль людського життя та здоров'я, котрі є обов'язковим додатковим об'єктом досліджуваних кримінальних правопорушень знецінюються умовами, у яких вчиняються останні.

Принцип побудови Особливої частини КК України 2001р. обумовлюе факт визнання родовим об'єктом злочинів проти безпеки руху та експлуатації транспорту - безпеку руху та безпеку експлуатації транспорту. Розглядаючи етимологічний зміст термінів, що утворюють словосполучення «безпека руху та експлуатації транспорту», необхідно вказати на таке. Безпека - це стан, коли кому-, чому-небудь ніщо не загрожує [4, с. 195]. Рух транспорту - це його переміщення, зміна положення [4, с. 195]. Експлуатація транспорту - це його використання [4, c. 195]. Як бачимо, зміст терміна «експлуатація транспорту» охоплює собою зміст терміна «рух транспорту», бо рух транспорту $\epsilon$ проявом його використання. Тим не менше, вживання обох термінів є доцільним. Пояснюється це тим, що рух транспорту унормовується самостійно. Наприклад, Правилами дорожнього руху [4, с. 195]. Крім того, слід відзначити, що безпека руху торкається не лише самого транспорту, а й учасників руху. Так, Закон України «Про дорожній рух» [4, c. 195] учасниками дорожнього руху визначає осіб, які використовують автомобільні дороги, вулиці, залізничні переїзди або інші місця, призначені для пересування людей та перевезення вантажів за допомогою транспортних засобів. До учасників дорожнього руху належать водії та пасажири транспортних засобів, пішоходи, велосипедисти, погоничі тварин. Безумовно, що названі особи 6 i учасниками руху інших транспортних засобів. Адже весь транспорт покликаний задовольняти потреби населення та суспільного виробництва в перевезеннях. Враховуючи викладене, в контексті словосполучення «безпека руху та експлуатації транспорту», безпеку руху транспорту можна визначити як прояв експлуатації транспорту, що проявляється в його переміщенні за призначенням за умов, що запобігають небезпеці [4, с. 196]. Ми абсолютно погоджуємось із останнім підходом, оскільки експлуатація транспорту та його рух є взаємозалежними поняттями, оскільки у більшості випадків рух є одним із способів експлуатації. Окрему увагу необхідно звернути на те, що учасниками дорожнього руху є водії та пасажири транспортних засобів, пішоходи, велосипедисти, погоничі тварин. Таким чином, законодавець окреслив достатньо широкий перелік суб'єктів, котрі можуть порушити безпеку дорожнього руху.

Вчені вказують, що безпеку експлуатації транспорту можна визначити як використання транспорту (крім його руху, що виокремлено як самостійний вид експлуатації) відповідно до технічних вимог, що усуває небезпеку. У цілому ж, безпеку руху та експлуатації транспорту можна визначити як такий стан функціонування транспорту, коли працівники транспорту, інші учасники 
руху дотримуються нормативно визначених встановлень у сфері експлуатації транспорту та безпеки руху, за яких створюються умови відсутності будь-яких загроз (небезпек). Безпека руху та безпека експлуатації транспорту кримінально-правовою охороною забезпечуються не самі по собі. Так, вчинення злочинів проти безпеки руху та експлуатації транспорту може загрожувати власне безпеці людини, екологічній безпеці. Наприклад, при порушенні працівником залізничного, водного або повітряного транспорту правил безпеки руху або експлуатації транспорту, а також недоброякісному ремонті транспортних засобів, колій, засобів сигналізації та зв'язку, якщо це створило небезпеку для життя людей або настання інших тяжких наслідків (ч.1 ст.276 КК України). Шкода при вчиненні злочинів проти безпеки руху та експлуатації транспорту може спричинятись також життю або здоров'ю людини. Наприклад, при умисному руйнуванні або пошкодженні шляхів сполучення, споруд на них, рухомого складу або суден, засобів зв'язку чи сигналізації, а також інші дії, спрямовані на приведення зазначених предметів у непридатний для експлуатації стан, якщо це спричинило потерпілому середньої тяжкості чи тяжкі тілесні ушкодження (ч.2 ст.277 КК України) або якщо спричинило загибель людей (ч.3 ст.277 КК України). Шкода при вчиненні злочинів проти безпеки руху та експлуатації транспорту може спричинятись і волі людини [4, с. 196]. У цьому контексті варто звернути увагу на те, що при вчиненні кримінальних правопорушень у сфері безпеки дорожнього руху, шкода завдається низці загальновизнаних цінностей та суспільних відносин, котрі охороняються кримінальним законодавством. Так, однією 3 таких цінностей (звичайно, окрім життя та здоров'я) є власність.

Наприклад, при угоні або захопленні залізничного рухомого складу, повітряного, морського чи річкового судна (ст.278 КК України). Шкода при вчиненні злочинів проти безпеки руху та експлуатації транспорту може спричинятись і власності. Наприклад, при вчиненні незаконного заволодіння транспортним засобом (ст.289 КК України). Шкода при вчиненні злочинів проти без- пеки руху та експлуатації транспорту може спричинятись і екологічній безпеці, громадській безпеці, правам і законним інтересам підприємств, установ, організацій та громадян. Наприклад, при пошкодженні об'єктів магістральних нафто-, газо- та нафтопродуктопроводів (ст.292 КК України). Як бачимо, сенс кримінально-правового забезпечення охорони безпеки руху та безпеки експлуатації транспорту - це створення при русі та експлуатації транспорту безпечних умов людині (ії життю, здоров’ю, безпеці, волі), забезпечення належного порядку користування власністю, забезпечення екологічної безпеки, громадської безпеки, прав і законних інтересів підприємств, установ, організацій та громадян. Тому, визначаючи родовий об'єкт злочинів, відповідальність за вчинення яких передбачена в XI розділі Особливої частини КК України 2001p., їх родовим об'єктом логічно визнавати відносини у сфеpi безпеки руху та експлуатації транспорту, що убезпечують життя, здоров’я, волю, безпеку людини, власність фізичних або юридичних осіб, екологічну безпеку, громадську безпеку, права і законні інтереси підприємств, установ, організацій та громадян. 3 приводу «нерозривності» безпеки руху та експлуатації транспорту з особистими благами людини (життям, здоров'ям, волею, безпекою) власністю, екологічною безпекою, громадською безпекою, правами і законними інтересами підприємств, установ, організацій та громадян, при визначенні об'єкта злочинів проти безпеки руху та експлуатації транспорту в теорії кримінального права єдності немає [4, с. 197]. Таким чином, досліджувана нами низка суспільно небезпечних діянь може порушувати безліч напрямків людського буття, котрі охороняються державою в межах кримінального законодавства.

Об'єкт злочинів проти безпеки руху та експлуатації транспорту в теорії кримінального права визначався неоднозначно. У цілому можна виділити дві позиції авторів. Одні (перша група авторів) стверджували, що поряд з безпекою руху та експлуатацією транспорту об'єктами злочину виступали життя, здоров'я, власність особи (у тих транспортних злочинах, де ці блага пошкоджу- 


\section{Кримінальне право, кримінальний процес та криміналістика}

вались). Інші (друга група авторів) вважали, що життя, здоров’я, власність не впливає на сутність транспортного злочину, хоча вони і пошкоджувались [4, с. 196]. Як зазначає О.О. Дудоров, займаючи проміжне становище між родовим і безпосереднім об'єктами, будучи частиною родового об'єкта і знаходячись 3 останнім у співвідношенні «вид»«рід», видовий об'єкт дає змогу виокремити специфічні групи злочинних посягань на близькі, взаємопов'язані суспільні відносини. Можна виокремити такі видові об'єкти в родовому об'єкті злочинів проти безпеки руху та експлуатації транспорту: безпека руху та експлуатації залізничного транспорту; безпека руху та експлуатації морського та річкового транспорту; безпека руху та експлуатації автомобільного транспорту та міського електротранспорту; безпека руху та експлуатації авіаційного транспорту; безпека руху та експлуатації магістрального трубопровідного транспорту. На підставі цього доцільним вважаємо використання такої класифікації злочинів проти безпеки руху та експлуатації транспорту: злочини проти безпеки руху та експлуатації залізничного транспорту; злочини проти безпеки руху та експлуатації морського та річкового транспорту; злочини проти безпеки руху та експлуатації автомобільного транспорту та міського електротранспорту; злочини проти безпеки руху та експлуатації авіаційного транспорту; злочини проти безпеки руху та експлуатації магістрального трубопровідного транспорту. В умовах запропонованої праці поняття та зміст злочинів у сфері безпеки дорожнього руху співпадає з поняттям та змістом злочинів проти безпеки руху та експлуатації автомобільного транспорту та міського електротранспорту. 3 нашої точки зору, така класифікація злочинів проти безпеки руху та експлуатації транспорту надасть змогу більш детального дослідження тих суспільних відносин, за посягання на які встановлено кримінальну відповідальність розділом XI Особливої частини КК України та сприятиме підвищенню ефективності правозастосовної практики у цьому напрямі [1, с. 55-57]. Що стосується кримінальних правопорушень у сфері безпеки дорожнього руху, то до останніх необхідно віднести наступні: пошкодження шляхів сполучення і транспортних засобів (ст. 277); блокування транспортних комунікацій, а також захоплення транспортного підприємства(ст. 279); примушування працівника транспорту до невиконання своїх службових обов'язків (ст. 280); порушення правил безпеки дорожнього руху або експлуатації транспорту особами, які керують транспортними засобами (ст. 286); порушення правил безпеки дорожнього руху або експлуатації транспорту особами, які керують транспортними засобами в стані сп'яніння (ст. 286-1); випуск в експлуатацію технічно несправних транспортних засобів або інше порушення їх експлуатації (ст. 287); порушення правил, норм і стандартів, що стосуються забезпечення дорожнього руху (ст. 288); знищення, підробка або заміна номерів вузлів та агрегатів транспортного засобу (ст. 290); порушення чинних на транспорті правил (ст. 291).

Відтак, об'єктом ст.ст. 279-291 у більшості випадків є безпека руху або експлуатації транспорту та його нормальна робота, життя та здоров'я людей, власність, порядок обліку і реєстрації транспортних засобів у сфері дорожнього руху. Передбачені цінності вказують на підвищену суспільну небезпечність такого роду протиправних діянь, котрі мають складну та розгалужену систему суспільно небезпечних наслідків. Саме у зв'язку із цим у 2021 році законодавцем було значно посилено кримінальну відповідальність за ці кримінальні правопорушення (особливо це стосується Загальної частини КК України в частині особливостей звільнення від кримінальної відповідальності та покарання), а також доповнено Кримінальний кодекс 2001 року нормою під номером 286-1, яка передбачає відповідальність за порушення правил безпеки дорожнього руху або експлуатації транспорту особами, які керують транспортними засобами в стані сп'яніння. Такий підхід, на наш погляд, є цілком зрозумілим, оскільки відповідно до статистичних даних, саме керування транспортним засобом у стані сп'яніння стає причиною більшості дорожньо-транспортних пригод. Окрему увагу необхідно звернути і на те, що майже половина з розглядуваних нами пра- 
вопорушень є предметними, і у більшості випадків предметом є шляхи сполучення та їх обладнання, споруди на них, транспортні засоби залізничного, повітряного, водного транспорту, засоби зв’язку чи сигналізації, а також інші транспортні комунікації, що забезпечують нормальну роботу залізничного, водного, повітряного, автомобільного, міського електричного або магістрального трубопровідного транспорту. Ще одним цікавим предметом є вокзали, станції, аеропорти, аеровокзали, гелікоптерні майданчики, автовокзали, порти, насосні станції тощо. У цьому контексті звернемо увагу на те, що законодавець за допомоги кримінально-правових засобів захистив максимальну кількість об'єктів, котрі відносяться до транспорту, а пов'язані з його обслуговуванням.

Що стосується об'єктивної сторони розглядуваних нами правопорушень, зазначимо, що ії утворюють: 1) умисне руйнування або пошкодження шляхів сполучення, транспортних засобів, їх комунікацій, засобів зв' язку чи сигналізації, а також вчинення інших діянь, що приводять зазначені об'єкти у непридатний для експлуатації стан;2) влаштування перешкод; 3) відключення енергопостачання; 4) інші способи. Як перешкоди можуть бути використані транспортні засоби, шлагбауми, троси, завали, гідротехнічні споруди та інші об'єкти і предмети, що порушують (або можуть порушити) нормальну і безпечну роботу транспорту; 5) активні дії щодо працівника транспорту 3 метою домогтися невиконання ним своїх службових обов'язків; 6) порушення правил безпеки дорожнього руху або експлуатації транспорту; 7) суспільно небезпечні наслідки; 8) причинний зв'язок між порушенням і наслідками; 9) випуск в експлуатацію завідомо технічно несправних транспортних засобів; 10) допуск до керування транспортним засобом особи, яка перебуває в стані сп'яніння чи не має права на керування транспортним засобом; 11) інше грубе порушення правил експлуатації транспорту, що убезпечують дорожній рух; 12) спричинення суспільно небезпечних наслідків;13) причинний зв’язок між порушенням правил експлуатації і суспільно небезпечними наслідками;14) порушення правил, норм і стандартів, що стосуються убезпечення дорожнього руху; 15) настання суспільно небезпечних наслідків; 16) причинний зв'язок між порушенням зазначених правил, норм і стандартів і настанням наслідків, передбачених у диспозиції статті; 17) дії, пов'язані зі знищенням, підробкою або заміною ідентифікаційного номера транспортного засобу або його частин (агрегатів) - двигуна, шасі, кузова (коляски, причепу), що присвоюються підприємством, яке його виготовило;18) дія або бездіяльність особи, пов'язана 3 порушенням чинних на транспорті правил, а також правил, норм і стандартів виготовлення, переобладнання, ремонту транспортних засобів, що убезпечують рух;19) суспільно небезпечні наслідки; 20) причинний зв'язок між порушенням і наслідками [1]. Таким чином, можна сказати, що вказані дії визнані максимально суспільно небезпечними та можуть спричинити значну шкоду не тільки державі, а і людині, як тій, що має безпосереднє відношення до цих об'єктів, так і для оточення.

Більш складну та цікаву характеристику має суб'єктивна сторона досліджуваних правопорушень, у зв'язку із чим пропонуємо розглянути їі більш детально.

Відтак, суб'єктивна сторона кримінального правопорушення, передбаченого ст. 277, має складний характер. Відносно власне руйнування, пошкодження, приведення предмета у непридатний для експлуатації стан іншим способом вчиняються з умислом (прямим і непрямим). Щодо тяжких наслідків, то можливий як умисел, так і необережність. Таким чином, це кримінальне правопорушення може вчинятись як у рамках однієї вини (умислу), так і в рамках складної форми вини - умислу щодо дій і необережність щодо наслідків. Мотиви пошкодження або руйнування можуть бути різноманітними (корисливі, хуліганські, помста працівникам, керівникам транспортних організацій тощо). Характер мотиву та форма вини до тяжких наслідків на кваліфікацію не впливають, але враховуються при призначенні покарання. Психічне ставлення суб'єкта до наслідків, передбачених у ч. ч. 2 і 3 , має бути необережним. Суб'єктом може бути фізична осудна особа, яка досягла до моменту вчи- 


\section{Кримінальне право, кримінальний процес та криміналістика}

нення злочину 14-річного віку. Закон не обмежує коло суб'єктів [1]. До речі, необхідно звернути увагу на те, що у випадку кримінальних правопорушень у сфері безпеки дорожнього руху дуже часто має місце або непрямий умисел, або необережність (у формі кримінально протиправної самовпевненості або недбалості). Саме тому дуже цікавим є те, що, не зважаючи на таку суб'єктивну сторону, вони мають значну суспільну небезпечність.

У ст. 279 КК України суб'єктивна сторона кримінальних правопорушень, передбачених ч. 1 або ч. 2 характеризується прямим умислом щодо дій. Мотиви і мета на кваліфікацію не впливають, а враховуються при призначенні покарання. Суб'єкт - фізична осудна особа, яка досягла 16-річного віку. При цьому ним може бути працівник транспорту [1]. Суб'єктивна сторона ст. 280 КК України характеризується прямим умислом: особа усвідомлює суспільно небезпечний характер свого діяння і бажає його вчинити. Мотиви та мета можуть бути різними і на кваліфікацію не впливають, але можуть бути врахованими при призначенні покарання. До наслідків, зазначених у ч. 3 ст. 280, вина може бути лише необережною. Суб'єктом є особа, яка досягла до часу вчинення злочину 16-річного віку. Якщо правопорушення вчинюе службова особа, яка використовує своє службове становище щодо підлеглих, діяння кваліфікується за сукупністю [1]. Вказані кримінальні правопорушення мають значну суспільну небезпечність, оскільки включають у свою об'єктивну сторону насильницький аспект, котрий полягає у блокуванні транспортних комунікацій, а також захоплення транспортного підприємства та примушуванні працівника до невиконання своїх обов'язків.

У ст. 286 КК України кримінальне правопорушення може бути вчинене тільки при керуванні транспортними засобами, які зазначені в примітці до статті. Суб'єктивна сторона характеризується необережною формою вини, що визначається характером ставлення винного до наслідків. Суб'єктом є особа, яка до часу його вчинення досягла 16річного віку. Не мають значення обставини, пов'язані з відсутністю в особи права на ке- рування транспортним засобом або позбавленням їі такого права в адміністративному чи судовому порядку, а також з тим, чи є вона працівником транспорту. Не є обов'язковою ознакою суб'єкта його відношення до транспортного засобу, тобто чи є він власником або орендарем транспортного засобу, керує ним за дорученням або незаконно заволодів ним. За порушення правил безпеки дорожнього руху під час їзди на навчальній автомашині з метою практичного навчання водінню відповідальність за певних умов несе особа, яка навчає водінню іншу особу і перебуває під час навчальної їзди поруч із учнем (майстер виробничого навчання, інструктор тощо), якщо вона не вжила необхідних заходів для відвернення суспільно небезпечних наслідків. У разі якщо особа, яка навчається керуванню, всупереч вказівкам інструктора вчинює порушення правил безпеки дорожнього руху або експлуатації транспорту, що тягне суспільно небезпечні наслідки, яким інструктор не мав реальної можливості запобігти, вона підлягає кримінальній відповідальності на загальних засадах. [1]. Окрему увагу в цьому контексті хочемо звернути на новелу кримінального законодавства - ст. 286-1 КК України, основною ознакою якої $\epsilon$ керування транспортним засобом у стані сп'яніння. Наразі в Україні ведеться боротьба 3 такими випадками. Звичайно, суб'єктивна сторона є дуже схожою із аналогічною в ст. 286 Кодексу. Однак, при цьому показовим є те, що необережні наслідки безпосередньо пов'язані із умислом по відношенню до створення умов, у яких водій втрачає можливість об'єктивно оцінювати дорожній рух, що спричиняє порушення правил його безпеки.

У ст. 287 КК України суб'єктивна сторона полягає в завідомості, тобто усвідомленні суб'єктом наявності технічної несправності транспортного засобу, що реально загрожує безпеці руху, або іншого грубого порушення правил експлуатації транспорту, яке для нього є очевидним та унеможливлює експлуатацію транспортного засобу, а тому закон говорить про умисел. Щодо наслідків, які настали, то винна особа передбачає можливість їх настання, але легковажно розраховує на їх відвернення або не передбачає 
можливості настання таких наслідків, хоча повинна була і могла їх передбачити. У цілому це діяння визнається необережним. Якщо ж буде встановлений у винного умисел до наслідків, то відповідальність настає за умисне кримінальне правопорушення проти особи. Суб’єктом можуть бути працівники транспортних та інших підприємств, установ і організацій незалежно від форми власності, на яких законом або підзаконними нормативними актами (інструкціями, правилами, розпорядженнями та ін.) покладено відповідальність за технічний стан чи експлуатацію транспортних засобів (завідувачі та начальники гаражів, інспектори безпеки руху, головні механіки, ревізори, власники та водії таких засобів, які дозволили іншим особам керувати останніми, тощо). Службові особи, які не є суб'єктами цього злочину, але внаслідок зловживання службовим становищем чи несумлінного виконання своїх обов'язків сприяли настанню тяжких наслідків, з урахуванням конкретних обставин справи можуть нести кримінальну відповідальність за злочини у сфері службової діяльності [1]. Таким чином, у цьому контексті можна констатувати наявність полісуб'єктості.

3 суб'єктивної сторони кримінальне правопорушення, передбачене ст. 288 КК України, загалом належить до необережних. Aле щодо самого порушення правил, норм або стандартів щодо убезпечення дорожнього руху, то воно може бути як умисним, так і необережним, відношення до наслідків тільки необережне. Винна особа передбачає можливість настання наслідків, зазначених у законі, але легковажно розраховує на їх відвернення (злочинна самовпевненість) або не передбачає можливості настання таких наслідків, хоча повинна була і могла їх передбачити (злочинна недбалість). Суб'єктом можуть бути 16-річні осудні особи, які виконують такі роботи або відповідальні за їх проведення: керівники дорожньо-експлуатаційних підприємств, їхні підлеглі, котрим надано повноваження щодо дотримання відповідних правил, норм і стандартів, та рядові працівники зазначених підприємств; інспектори безпеки руху; виконроби, майстри, інші особи, які керують проведенням дорожних робіт чи робіт у межах проїзної частини; тощо [1]. Особливістю розглядуваних кримінальних правопорушень є те, що більшість із них має змішану форму вини.

У ст. 290 КК України суб'єктивна сторона кримінального правопорушення характеризується прямим умислом. Суб'єктом може бути осудна особа, яка на момент його вчинення досягла 16-річного віку. Що стосується ст. 291 КК України, суб'єктивна сторона характеризується необережною виною: особа передбачає можливість настання суспільно небезпечних наслідків, але легковажно розраховує на їх відвернення або не передбачає можливості настання таких наслідків, хоч повинна була і могла їх передбачити. Суб'єктами можуть бути: велосипедисти, пішоходи, пасажири, водії мопедів, маломірних суден, погоничі тварин, водії гужового транспорту. Це також можуть бути автослюсарі, майстри, наладчики обладнання, керівники ремонтних ділянок, контролери якості. Не підлягають відповідальності за цією статтею особи, які є суб'єктами діянь, передбачених ст. 276, 277, 283, 286, 287, 288 [1]. Отже, у цьому випадку особливе значення під час кваліфікації має встановлення відношення та оцінки суб'єктом своїх дій.

Таким чином, проведене дослідження дозволило підсумувати, що кримінальні правопорушення у сфері безпеки дорожнього руху мають дуже специфічні склади, котрі під час кримінально-правової характеристики потребують урахування низки особливостей. Дуже показовим у цьому контексті є також те, що при зовнішній схожості кожне 3 цих суспільно небезпечних діянь 6 індивідуальним та потребує ретельного підходу.

\section{Лiтература}

1. Назимко E.С., Пилипенко E.O., Лосич С.В., Печук I.С. Кримінальна відповідальність за злочини у сфері безпеки дорожнього руху: навчальний посібник. Донецьк: «Цифрова типографія», 2013. 178 с.

2. Короленко О.В. Кримінологічна характеристика злочинів проти безпеки руху та експлуатації транспорту: автореферат роботи на здобуття освітнього ступеня «Магістр». Чорноморський Національний 


\section{Кримінальне право, кримінальний процес та криміналістика}

Університет імені Петра Могили. Миколаїв, 2021. 20 c.

3. Ардашкин В. Д. К теории правоохранительного механизма // Правоведение. 1988. - № 1. - С. 1-7.

4. Осадчий В.І. Об'єкт транспортних злочинів. Вісник Національного технічного університету Украйни «Киӥвський політехнічний інститут». Політологія. Соиіологія. Право. 2012. № 3. C. 194-201

\section{CRIMINAL AND LEGAL CHARACTER- ISTICS OF CRIMINAL OFFENSES IN THE FIELD OF ROAD SAFETY}

In the article the author gives the criminallegal characteristic of criminal offenses in the field of road safety. Indicates the lack of a comprehensive scientific assessment of the phenomenon of the object of a criminal offense. Currently, there is a number of scientific studies in this area, as the object plays a leading role in the formation of sections of criminal law, as it allows you to create a set of illegal acts for the same motive and purpose, while most issues remain unresolved. The author points out the preference for the standard approach of sup- porters of domestic criminal law, according to which the object of a criminal offense is, first of all, public relations in a particular area. It is stated that in the context of the article, for the most part, the immediate object is the safety of movement and operation of road and some other modes of transport, and its additional mandatory object - the life and health of the person, as well as property. It is noted that the values provided for in the criminal legislation indicate an increased social danger of criminal offenses in the field of road safety, which have a complex and extensive system of socially dangerous consequences. In this regard, in 2021 the legislator significantly strengthened the criminal liability for these criminal offenses (especially, this applies to the General Part of the Criminal Code of Ukraine in terms of features of exemption from criminal liability and punishment), and supplemented the Criminal Code of 2001 286-1, which provides for liability for violation of traffic safety rules or operation of transport by persons driving while intoxicated. In conclusion, this approach is quite understandable, because according to statistics, it is driving while intoxicated that is the cause of most accidents.

Key words: criminal offense, criminal-legal characteristic, safety, traffic, transport, driver, means of transport, state of intoxication. 